\title{
Optimum Timing of Preplant Applications of Glyphosate to Manage Rhizoctonia Root Rot in Barley
}

E. M. Babiker and S. H. Hulbert, Department of Plant Pathology, Washington State University, Pullman 99164-6430; and K. L. Schroeder and T. C. Paulitz, United States Department of Agriculture-Agricultural Research Service, Washington State University, Pullman

\begin{abstract}
Babiker, E. M., Hulbert, S. H., Schroeder, K. L., and Paulitz, T. C. 2011. Optimum timing of preplant applications of glyphosate to manage Rhizoctonia root rot in barley. Plant Dis. 95:304-310.

Rhizoctonia root rot, caused by Rhizoctonia solani AG-8 and $R$. oryzae, is considered one of the main deterrents for farmers to adopt reduced-tillage systems in the Pacific Northwest. Because of the wide host range of Rhizoctonia spp., herbicide application before planting to control weeds and volunteer plants is the main management strategy for this disease. To determine the effect of timing of glyphosate applications on the severity of Rhizoctonia root rot of barley, field experiments were conducted in 2007, 2008, and 2009 in a field naturally infested with a high level of both $R$. solani and $R$. oryzae. Crop volunteer plants and weeds were allowed to grow over the winter and plots were sprayed with glyphosate at $42,28,14,7$, and 2 days prior to

significant increases in shoot length, length of the first true leaf, and number of healthy seminal roots and a decrease in disease severity. Yield and the number of seminal roots did not show a response to herbicide application interval in most years. The activity of $R$. solani, as measured by toothpick bioassay and real-time polymerase chain reaction, declined over time in all treatments after planting barley. The herbicide application interval required to meet 80 and $90 \%$ of the maximum response (asymptote) for all plant and disease measurements ranged from 11 to 27 days and 13 to 37 days, respectively. These times are the minimum herbicide application intervals required to reduce disease severity in the following crop.
\end{abstract} planting. As the herbicide application interval increased, there were
There is increased interest in the Pacific Northwest (PNW) of the United States toward reduced-tillage systems in which crop residues are left on the soil surface rather than incorporated into the soil. Planting into uncultivated soil (no-till) reduces soil erosion, increases carbon sequestration in the soil, and increases water storage by improved water infiltration (18). Undisturbed soil and lower soil surface temperatures in no-till systems allow inoculum of several soilborne pathogens to thrive in crop residues, making diseases more aggressive in the following crop. Compared with countries such as Canada, Argentina, and Brazil, the adoption of no-till in the United States is still very low, particularly in the PNW (18). One of the main obstacles to adoption of reduced tillage in the PNW region is Rhizoctonia root rot caused by Rhizoctonia solani Kühn and $R$. oryzae Ryker \& Gooch (3). Given the wide host range of Rhizoctonia spp., which includes all of the rotation crops in the region as well as numerous grassy weeds, and the ability to persist saprophytically on crop residue, the disease is able to flourish under reduced-tillage systems (18).

Because there is no known natural resistance for this disease, different management strategies have been developed to reduce its severity in no-till cropping systems. These include using higherdisturbance seed row openers and placement of fertilizer below the seed to promote seedling health (21). The most effective control method in no-till systems is herbicide application before planting to control weeds and volunteer plants which act as a "green bridge" and support the pathogen population during the time from the harvest of previous crop to the sowing of the new crop (27).

In no-till systems in the PNW, weeds and volunteer plants are commonly controlled with the application of glyphosate, often

Corresponding author: T. C. Paulitz, E-mail: paulitz@wsu.edu

Accepted for publication 12 November 2010.

doi:10.1094/PDIS-05-10-0354

This article is in the public domain and not copyrightable. It may be freely reprinted with customary crediting of the source. The American Phytopathological Society, 2011. with planting following shortly thereafter to hasten crop establishment. Within a few days after the application of glyphosate, root rot pathogens grow rapidly in dying volunteer plants and weeds, resulting in increased disease in spring cereals that are planted into the same field (27). Similarly, recent studies have demonstrated that root rot caused by soilborne pathogens is greater in crops planted immediately after glyphosate application. In greenhouse studies of glyphosate-resistant sugar beet, Larson et al. (14) observed significant increase in disease severity caused by $R$. solani AG-2-2 isolate R-9 following glyphosate application. Sanogo et al. (24) also observed that glyphosate application increased the severity and frequency of Fusarium solani f. sp. glycines in the roots of glyphosate-resistant and non-glyphosate-resistant soybean cultivars. Bradley et al. (2) related this increase in soybean disease to the influence of herbicides on pathogen growth and virulence, host susceptibility, and an alteration of the relationships between the pathogen and beneficial microorganisms in the rhizosphere.

Glyphosate has been reported to target enolpyruvylshikimate-3phosphate synthase, the enzyme responsible for converting shikimate to chorismate in the shikimic acid pathway. This inhibition blocks the production of precursors necessary for the biosynthesis of aromatic compounds important for plant defense. This includes salicylic acid, phytoalexins, tyrosine, phenylalanine, and tryptophan (6). In addition, glyphosate application has been reported to induce sclerotia formation and increase sclerotia weight of $R$. solani AG-4 and $R$. solani AG-2-2, respectively (5).

Because glyphosate application may directly or indirectly increase the incidence of Rhizoctonia root rot in barley, concerns have been raised regarding the impact of glyphosate on soilborne diseases. Until now, little was known about the effect of preapplied glyphosate on $R$. solani populations. The objective of this research was to determine the effect of time intervals between glyphosate applications and planting date (herbicide application interval) on seedling health, the severity of Rhizoctonia root rot in barley, and $R$. solani populations.

\section{Materials and Methods}

Plots were established in 2007, 2008, and 2009 at the Agriculture Research Service Palouse Conservation Field Station near 
Pullman, WA, in an area with Thatuna fine silt loam soil and a previous history of $R$. solani and $R$. oryzae. The field had been in a winter wheat-spring wheat rotation for 4 years. To encourage development of the disease in these plots, volunteer plants and grassy weeds were allowed to grow over the winter.

The experimental design consisted of five or six preplant glyphosate applications, replicated four times in a randomized complete block design. Plots were sprayed with glyphosate (Alecto 41S; Ritter Chemical LLC, Houston) at a rate of $0.85 \mathrm{~kg} \mathrm{AE} / \mathrm{ha}$ in an overall volume of 112 liters/ha using a 2.43-m-wide hand-held gas-operated hooded boom sprayer. Applications were made at 2, 7, 14, 28, 42, and 56 days prior to planting in the 2007 experiment whereas, in 2008 and 2009, the 56-day treatment could not be applied because of snow cover. In 2007, 2008, and 2009, nontreated barley seed (Hordeum vulgare cv. Baronesse) were directly drilled into the soil to a depth of approximately $3 \mathrm{~cm}$ at a rate of $85 \mathrm{~kg} / \mathrm{ha}$ on 27 April, 28 April, and 1 May, respectively. Each plot had eight rows, $7.3 \mathrm{~m}$ in length, with $0.3 \mathrm{~m}$ between rows.

Five weeks after emergence at Feekes growth stage 2, 15 plants were randomly collected from each plot. Roots were washed to remove adhering soil and plants were evaluated for shoot length, length of first leaf, number of tillers, number of seminal roots, number of crown roots, number of infected seminal roots, number of infected crown roots, and percentage of healthy seminal and crown roots. Rhizoctonia root rot severity was assessed using a 0 to- 8 scale with the following criteria: $0=$ no lesions, $1=<50 \%$ of the roots with a single lesion, $2=<50 \%$ of the roots each with a few lesions, $3=>50 \%$ of the roots each with one or more lesions, 4 $=<50 \%$ of the roots with lesions within $1 \mathrm{~cm}$ of the seed, $5=$ $>50 \%$ of the roots with lesions within $1 \mathrm{~cm}$ of the seed, $6=>50 \%$ of the roots with terminal lesions less than $3 \mathrm{~cm}$ from the seed, $7=$ $>50 \%$ of the roots with terminal lesions less than $1 \mathrm{~cm}$ from the seed, and $8=100 \%$ of the roots with terminal lesions $<1 \mathrm{~cm}$ from the seed (11). Healthy root rating was calculated by subtracting the disease root rating from 8 .

To estimate the activity of $R$. solani and $R$. oryzae in 2007, a toothpick baiting assay was used (19). This baiting technique counts the number of Rhizoctonia colonies that arise from a toothpick inserted in the soil for $48 \mathrm{~h}$. The toothpicks are plated on a selective medium, and the hyphae that intersect a grid under a dissecting microscope are counted after $24 \mathrm{~h}$. Soils were sampled at planting and 5, 28, 42, and 74 days after planting. One shovel of soil was taken from each plot, the soil was mixed, and the toothpick baiting was performed on $140 \mathrm{~g}$ of soil from each sample. To estimate the population density of $R$. solani AG- 8 and $R$. oryzae in the soil in the 2008 and 2009 experiments, three random samples of about five barley plants each, with adhering soil, were collected from each plot during sampling. DNA was extracted from each soil sample as described by Okubara et al. (16). $R$. solani AG-8 and $R$. oryzae genotype II/III populations were monitored using real-time polymerase chain reaction (PCR) in combination with specific primers developed by Okubara et al. (17).

At the end of the season, grain yield was assessed by harvesting a 1.5-by-6.4-m strip from each plot using a Wintersteiger plot combine. After cleaning to remove chaff, grain was weighed to obtain yield estimates and test weights were determined by weighing a fixed volume of grain using a weight-filling hopper (Seedburo Equipment Co., Chicago).
Precipitation data was taken from the NOAA National Weather Service website (http://www.weather.gov/climate/index.php?wfo= otx) from a site located $7.5 \mathrm{~km}$ away, at the Pullman-Moscow Regional Airport, while the soil temperature was monitored at the depth of $16 \mathrm{~cm}$ on an adjacent field on the farm (Table 1).

Statistical analysis. Analysis of variance was calculated using Proc GLM in SAS (version 9.1; SAS Institute, Cary, NC). Means were compared using Fisher's protected least significant difference at $P=0.05$. Logistic regression analysis and correlation coefficient values were used to examine the relationship between different preplant herbicide application intervals and shoot length, length of first true leaf, number of seminal and crown roots, percentage of healthy seminal and crown roots, and healthy root rating using SigmaPlot software (version 6; SPSS, Inc. Chicago). A sigmoidal three-parameter model formula was used as follows: $Y=a / 1+e^{-(X-X o / b)}$, where $Y$ $=$ measured response, $x=$ time of herbicide application before planting, $x_{o}=$ predicted $x$ at $Y=0, a=$ maximum asymptote, and $b$ $=$ slope function.

To calculate the times at which 80 and $90 \%$ of the asymptote was reached, the following equation was used (solving for $\mathrm{X}$ ): $X=$ $X_{o}-b \times \ln \left(a / Y_{80,90}{ }^{-1}\right)$, where $\mathrm{Y}_{80}=[(a-\operatorname{minimum} Y) \times 0.8]+$ minimum $Y$ and where the minimum $Y=$ the predicted $Y$ value from the model for $X=2$ days.

Pearson's coefficient of correlation was used to examine the correlation between the Rhizoctonia root rot rating and seedling plant measurements of shoot length, length of first true leaf, and number of tillers.

\section{Results}

For most variables, except for the number of seminal roots and number of crown roots, there was a significant effect of herbicide application interval and year, and a significant interaction of herbicide application interval by year. Therefore, the responses were examined separately for each year. In all 3 years, the shoot length, length of first leaf, percentage of healthy seminal roots, and healthy root rating were significantly affected $(P<0.05)$ by herbicide application interval (Figs. 1 to 4$)$. The responses were asymptotic, with the slope of the response leveling off for longer intervals (Figs. 1 to 4). Therefore, a sigmoidal or logistic model was applied to the data, which showed significant $r^{2}$ and $P$ values for the models (Figs. 1 to 4 ). In all 3 years, based on regression analysis, there was a trend for an increase in shoot length, length of first true leaf, percent of healthy seminal roots, and healthy root rating as the herbicide application interval increased (Figs. 1 to 4). Additional plant and disease measurements gave varying results with year. In 2007 and 2008, the number of tillers and number of infected crown roots were significantly affected by herbicide application interval, as well as the number of crown roots in 2008 (Table 2). In 2009, none of these variables were affected by herbicide application interval, and the number of seminal roots was not affected in any of the 3 years. Yield was not significantly affected by herbicide application interval in 2 of the 3 years of the study (Fig. 5). However, in 2007, a sigmoidal regression model showed a significant $r^{2}$ and $P$ value for the model $(P=0.058$; Fig. 5$)$.

In order to calculate the maximum benefits of green bridge elimination and provide an accurate time for planting, a logistic curve equation was used to calculate the times at which 80 and

Table 1. Monthly precipitation and mean soil temperature at a depth of $16 \mathrm{~cm}$ for Pullman, WA

\begin{tabular}{|c|c|c|c|c|c|c|}
\hline \multirow[b]{2}{*}{ Month } & \multicolumn{3}{|c|}{ Precipitation $(\mathrm{mm})$} & \multicolumn{3}{|c|}{ Temperature $\left({ }^{\circ} \mathbf{C}\right)$} \\
\hline & 2007 & 2008 & 2009 & 2007 & 2008 & 2009 \\
\hline January & 58 & 63 & 71 & -0.4 & 0.4 & 0.5 \\
\hline February & 45 & 20 & 29 & 0.9 & 0.9 & 1.1 \\
\hline March & 35 & 46 & 99 & 4.9 & 3.3 & 2.5 \\
\hline April & 27 & 17 & 53 & 8.5 & 5.9 & 6.9 \\
\hline May & 29 & 32 & 57 & 11.9 & 12.5 & 12.2 \\
\hline June & 24 & 39 & 31 & 13.5 & 15.9 & 18 \\
\hline July & 6 & 6 & 25 & 20.6 & 31.6 & 21.4 \\
\hline
\end{tabular}


$90 \%$ of the maximum response were reached. The time to reach $80 \%$ of the maximum varied from 11 to 27 days, and the time to reach $90 \%$ varied from 13 to 37 days (Table 3 ). Time to achieve the 80 and $90 \%$ level was longer in 2008 than 2007 or 2009, except for the length of the first true leaf.

There was no significant effect of herbicide application interval on inoculum of Rhizoctonia spp. in 2007, using the toothpick baiting technique (Fig. 6). The activity of $R$. oryzae had a tendency to decline over time in all treatments after planting of barley. Based on DNA concentrations, there was a significant effect of herbicide application interval on inoculum of $R$. solani AG-8 in 2008 and 2009 ( $P<0.05$; Fig 7). In 2008, the highest quantity of $R$. solani AG-8 DNA was seen at the time of planting in the treatment sprayed out 7 days before. In 2009, the treatment sprayed out 2 days before had the highest DNA quantity. This increase in DNA concentration was associated with a trend for reduction in the number of healthy seminal roots and healthy root rating. In both years, the concentration of $R$. solani AG-8 DNA declined after an initial spike soon after herbicide application (Fig. 7). There was a strong
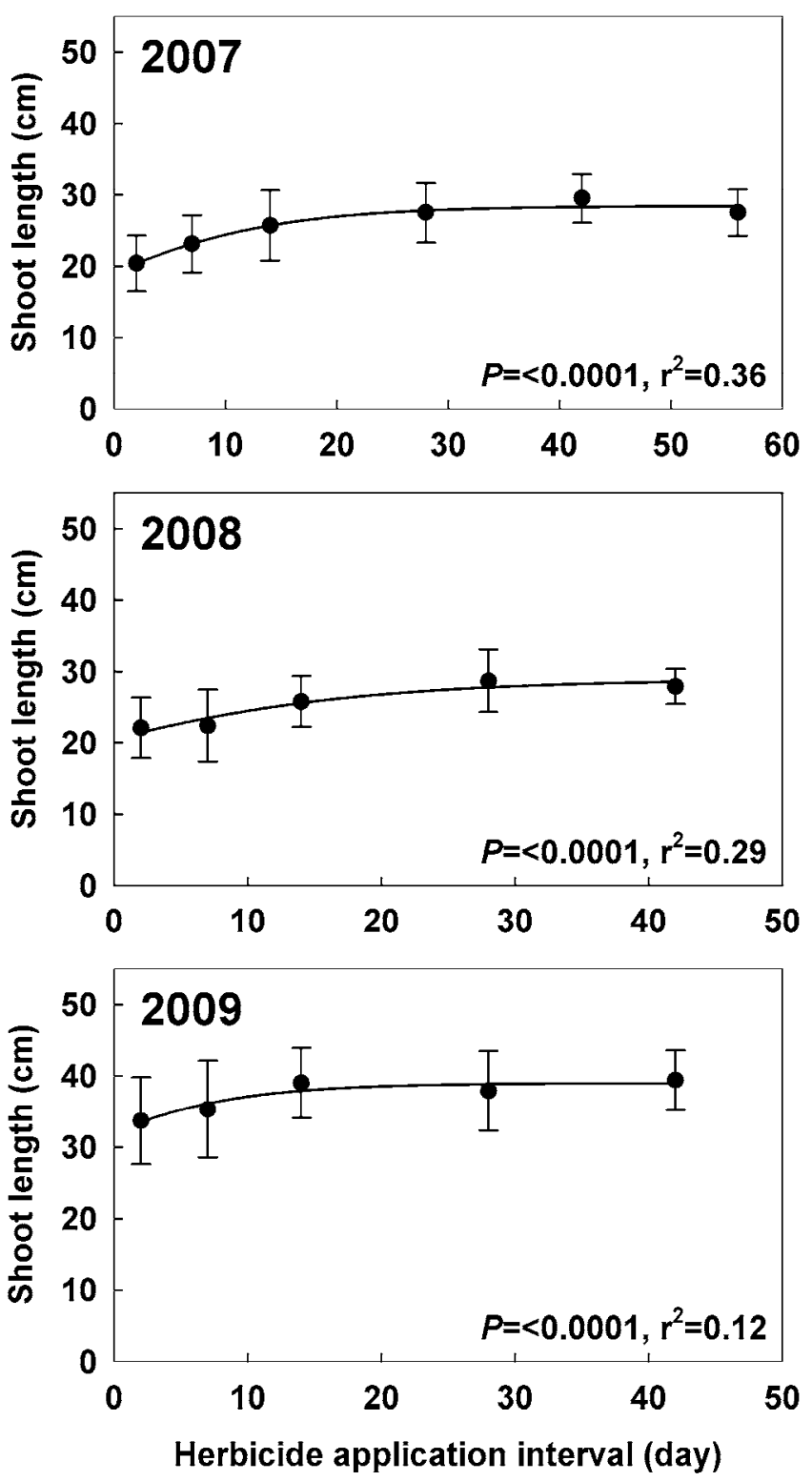

Fig. 1. Influence of herbicide application interval (time between glyphosate application and planting) on spring barley shoot length in Pullman, WA during 2007, 2008, and 2009. Bars indicate standard deviation of the mean. Points are fit with a logistic regression model. $P$ value for the analysis of variance and Fisher's protected least significant difference $(P=0.05)$ were $<0.0001$ and 1.96 in 2007, $<0.0001$ and 1.87 in 2008, and $<0.0001$ and 2.12 in 2009 , respectively. negative correlation (except for the number of tillers in 2009) between the disease rating and plant variables, although the probability for some correlations was above 0.05 (Table 4).

\section{Discussion}

Wheat growers in the PNW recognize the value of reducing the green bridge time interval to manage Rhizoctonia root rot but the optimal time of herbicide application before planting has not been definitely established. The recommendation of applying herbicides 3 weeks before planting has been based on the work of Smiley et al. (27). They found that herbicide treatments the previous autumn or 3 weeks before planting in the spring significantly reduced Rhizoctonia root rot of spring barley and increased yield, compared with applications 2 or 3 days before planting. However, they did not look at periods longer than 3 weeks, and only looked at 3 weeks to 2 days in one field year. The timing of glyphosate application is an important determinant of the incidence and severity of Rhizoctonia root rot. In each of 3 years, disease rating increased as the herbicide application interval decreased. Our results were sup-
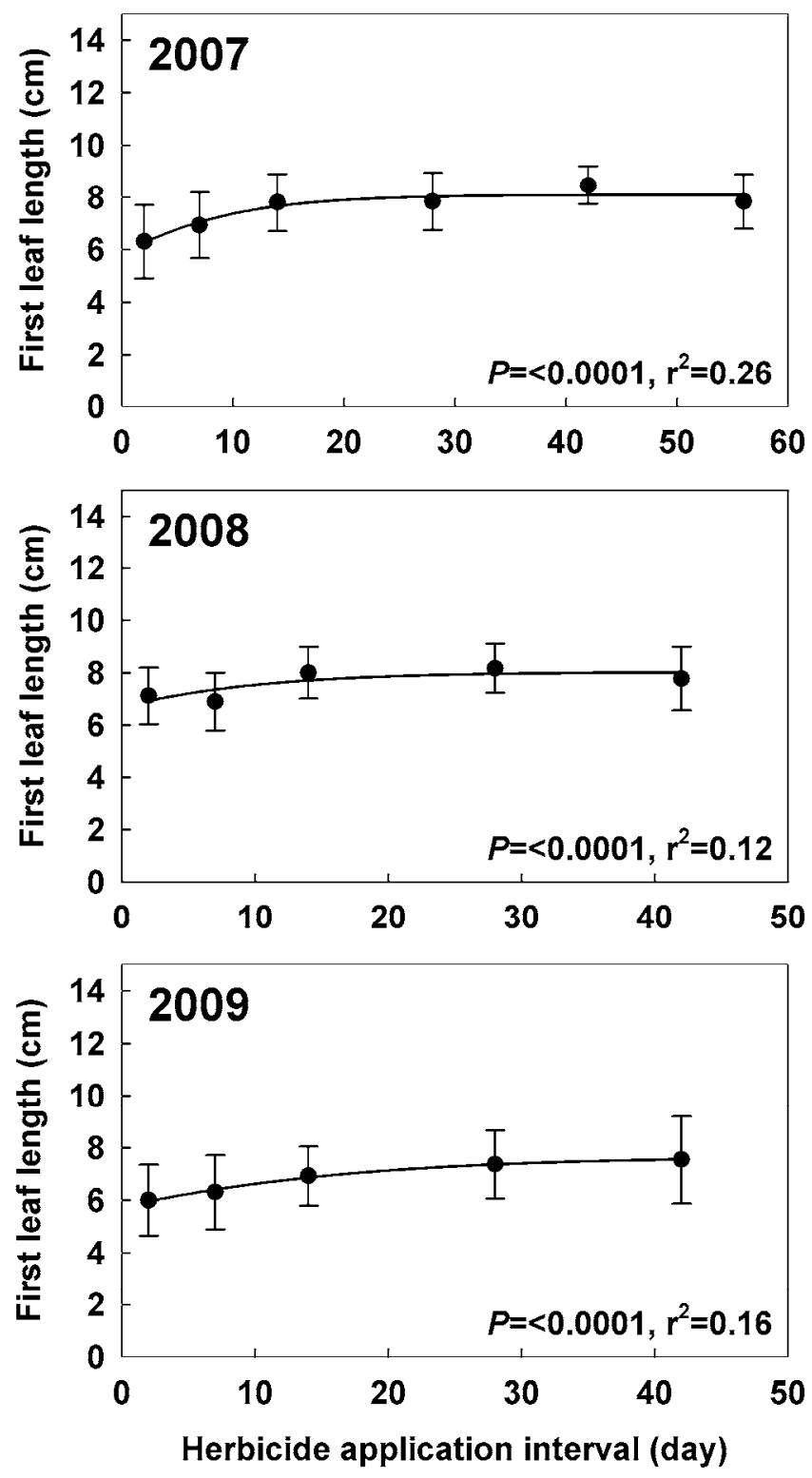

Fig. 2. Influence of herbicide application interval (time between glyphosate application and planting) on length of spring barley first true leaf in Pullman, WA during 2007, 2008, and 2009. Bars indicate standard deviation of the mean. Points are fit with a logistic regression model. $P$ value for the analysis of variance and Fisher's protected least significant difference $(P=0.05)$ were $<0.0001$ and 0.53 in $2007,0.0001$ and 0.54 in 2008, and 0.02 and 1.17 in 2009, respectively. 
ported by Roget (23), who observed that a 3- to 6-week interval between herbicide application and sowing significantly reduced Rhizoctonia root rot disease. Similarly, Jarvis and Brennan (9) observed that 17-day intervals between cultivation and seeding resulted in more patch and lower yields in wheat compared with 29day intervals. In all 3 years, shoot length, length of first leaf, and the number of healthy seminal roots increased as the interval after herbicide application increased. The response to herbicide application intervals was asymptotic. There was a positive response from about 2 to 21 days, after which the slope declined and a maximum was reached. Logistic regression analysis revealed a positive relationship between herbicide application interval periods and shoot length, percentage of healthy seminal roots, length of first true leaf, and healthy root rating. The key finding of this study is that an 11- to 27day interval between glyphosate application and planting is required to reduce the severity of the disease by $80 \%$ in the following crop.

Maximum healthy root ratings of $80 \%$ were observed at a $20-$, 25-, and 11-day interval in 2007, 2008, and 2009, respectively,
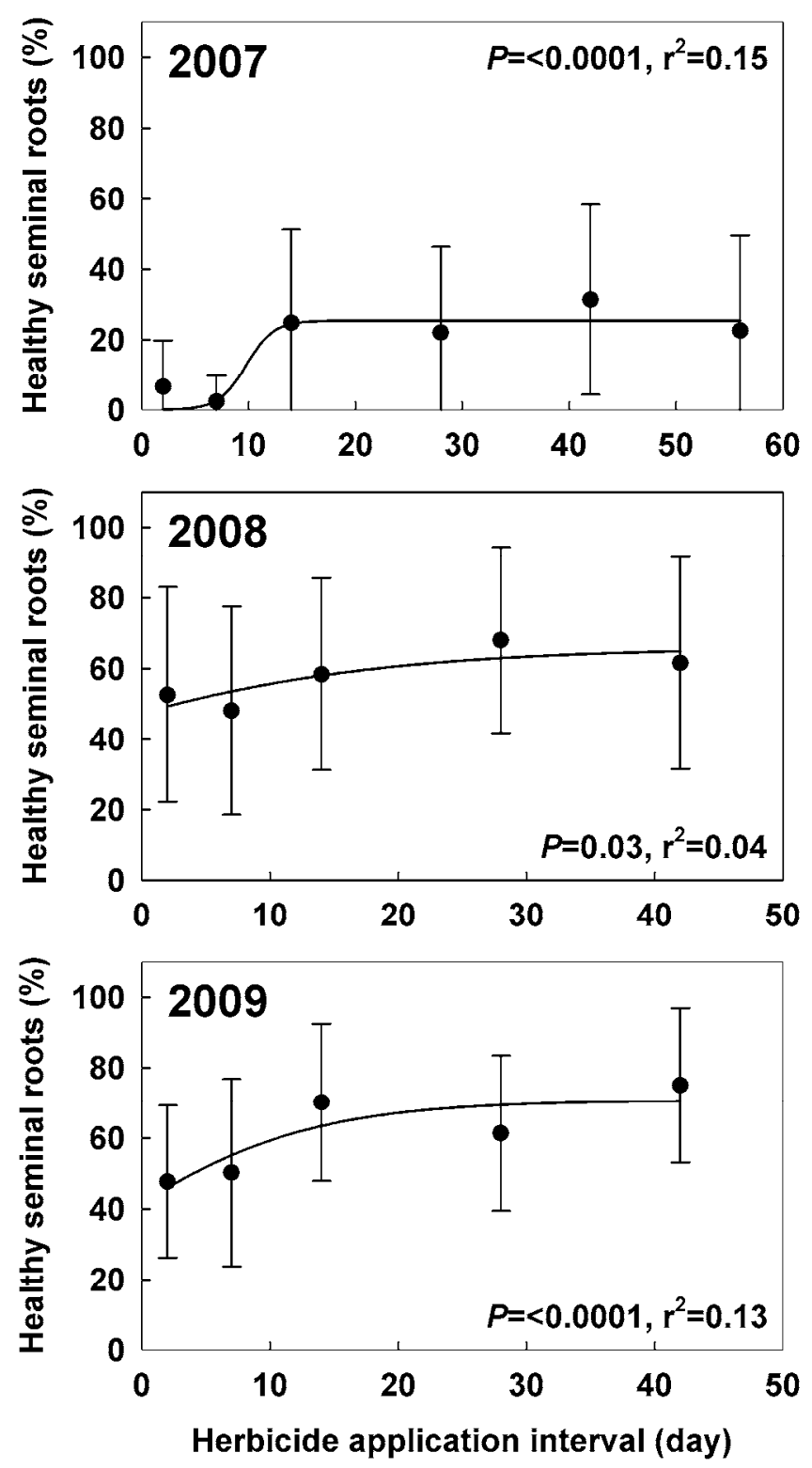

Fig. 3. Influence of herbicide application interval (time between glyphosate application and planting) on percentage of healthy spring barley seminal roots in Pullman, WA during 2007, 2008, and 2009. Bars indicate standard deviation of the mean. Points are fit with a logistic regression model. $P$ value for the analysis of variance and Fisher's protected least significant difference $(P=0.05)$ were $<0.0001$ and 8.91 in 2007, 0.03 and 13.70 in 2008, and <0.0001 and 9.40 in 2009, respectively. whereas 19-, 25-, and 14-day intervals were required to obtain $80 \%$ of the maximum in shoot length. Germination and emergence of volunteer plants and weeds is influenced by soil moisture and temperature and was considerably slower in 2009 than 2007 and 2008. This could explain why the time required to reach the point at which $80 \%$ of maximum in shoot length and percentage of healthy roots rating was shorter in 2009. In general, 2008 showed the longest interval required to achieve the reduction in disease and increase in shoot length. The average soil temperature and precipitation in April 2008 was lower than April 2007 and 2009 (Table 1). April 2008 was relatively cool, and more time may be necessary for the natural microbial activity to reduce the inoculum of Rhizoctonia spp. Eighty percent of the maximum in the length of the first leaf was observed at 15-, 18-, and 26-day intervals in 2007, 2008, and 2009, respectively. Reduction of the first leaf length is an indicator of infection by Pythium spp. The average monthly precipitation between January and June was $36 \mathrm{~mm}$ in 2007 and 2008 and $57 \mathrm{~mm}$ in 2009 (Table 1). This increase in soil moisture may have
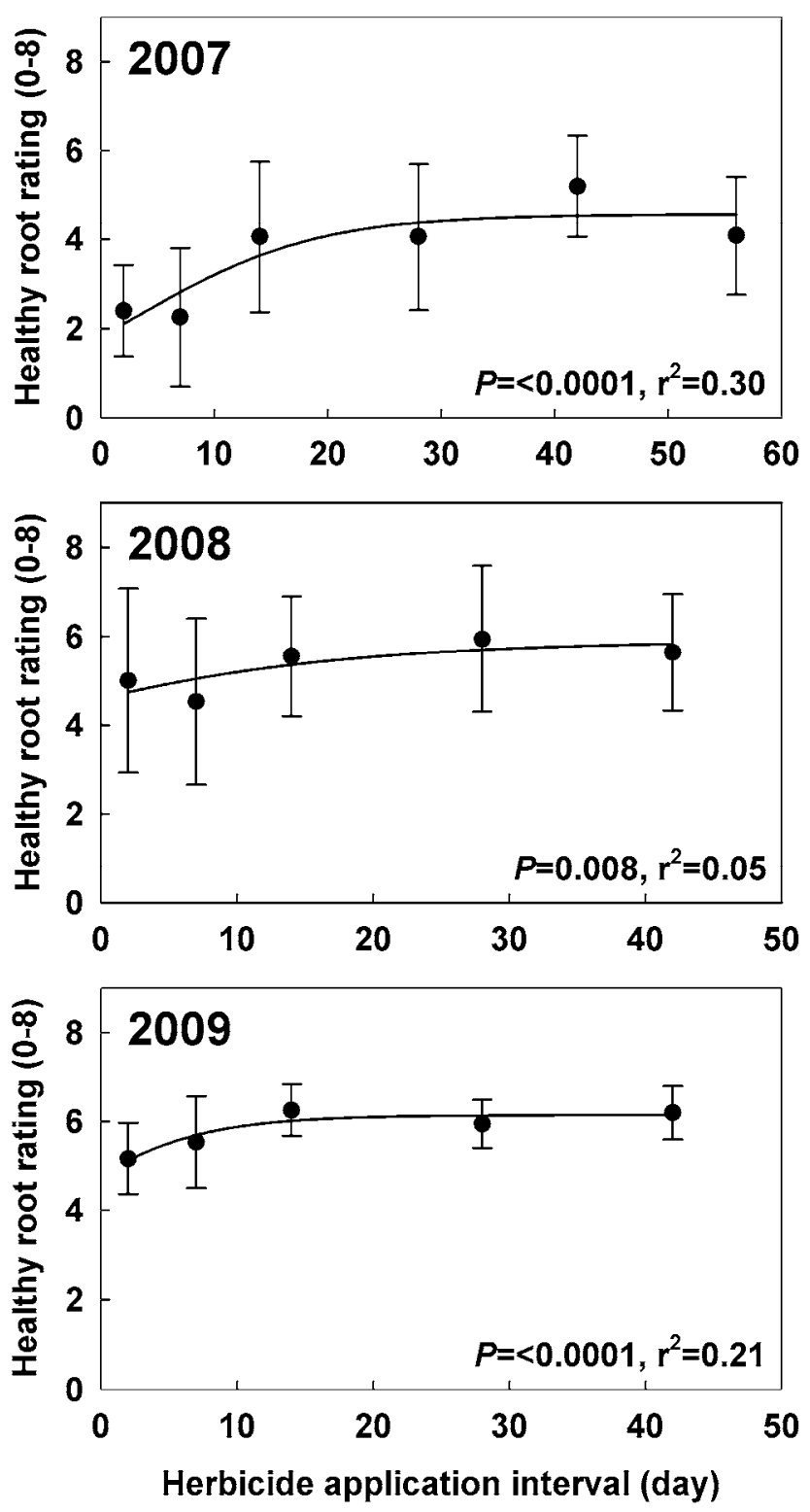

Fig. 4. Influence of herbicide application interval (time between glyphosate application and planting) on healthy spring barley root rating ( $8=$ healthy roots and $0=100 \%$ of roots with terminal lesions $<1 \mathrm{~cm}$ from seed) in Pullman, WA during 2007,2008 , and 2009. Bars indicate standard deviation of the mean. Points are fit with a logistic regression model. $P$ value for the analysis of variance and Fisher's protected least significant difference $(P=0.05)$ were $<0.0001$ and 0.60 in 2007 , 0.001 and 0.73 in 2008, and $<0.0001$ and 0.26 in 2009 , respectively. 
increased the Pythium spp. activity for a longer period of time in 2009.

The toothpick bioassay was not able to demonstrate a significant difference in Rhizoctonia spp. populations among the herbicide

Table 2. Analysis of variance to examine the influence of herbicide application intervals (time between glyphosate application and planting) on number of tillers, number of seminal roots, number of crown roots, and number of Rhizoctonia root rot-infected crown roots for spring barely in Pullman, WA ${ }^{\mathrm{a}}$

\begin{tabular}{ccccc}
\hline Year & $\begin{array}{c}\text { No. of } \\
\text { tillers }\end{array}$ & $\begin{array}{c}\text { No. of } \\
\text { seminal roots }\end{array}$ & $\begin{array}{c}\text { No. of } \\
\text { crown roots }\end{array}$ & $\begin{array}{c}\text { No. of } \\
\text { infected } \\
\text { crown roots }\end{array}$ \\
\hline 2007 & $<0.0001$ & $0.8^{*}$ & $0.37^{*}$ & 0.03 \\
2008 & 0.002 & $0.5^{*}$ & $<0.0001$ & 0.0001 \\
2009 & $0.09^{*}$ & $0.2^{*}$ & $0.14^{*}$ & $0.1^{*}$ \\
\hline
\end{tabular}

a Asterisk $(*)$ denotes nonsignificant $P$ values.
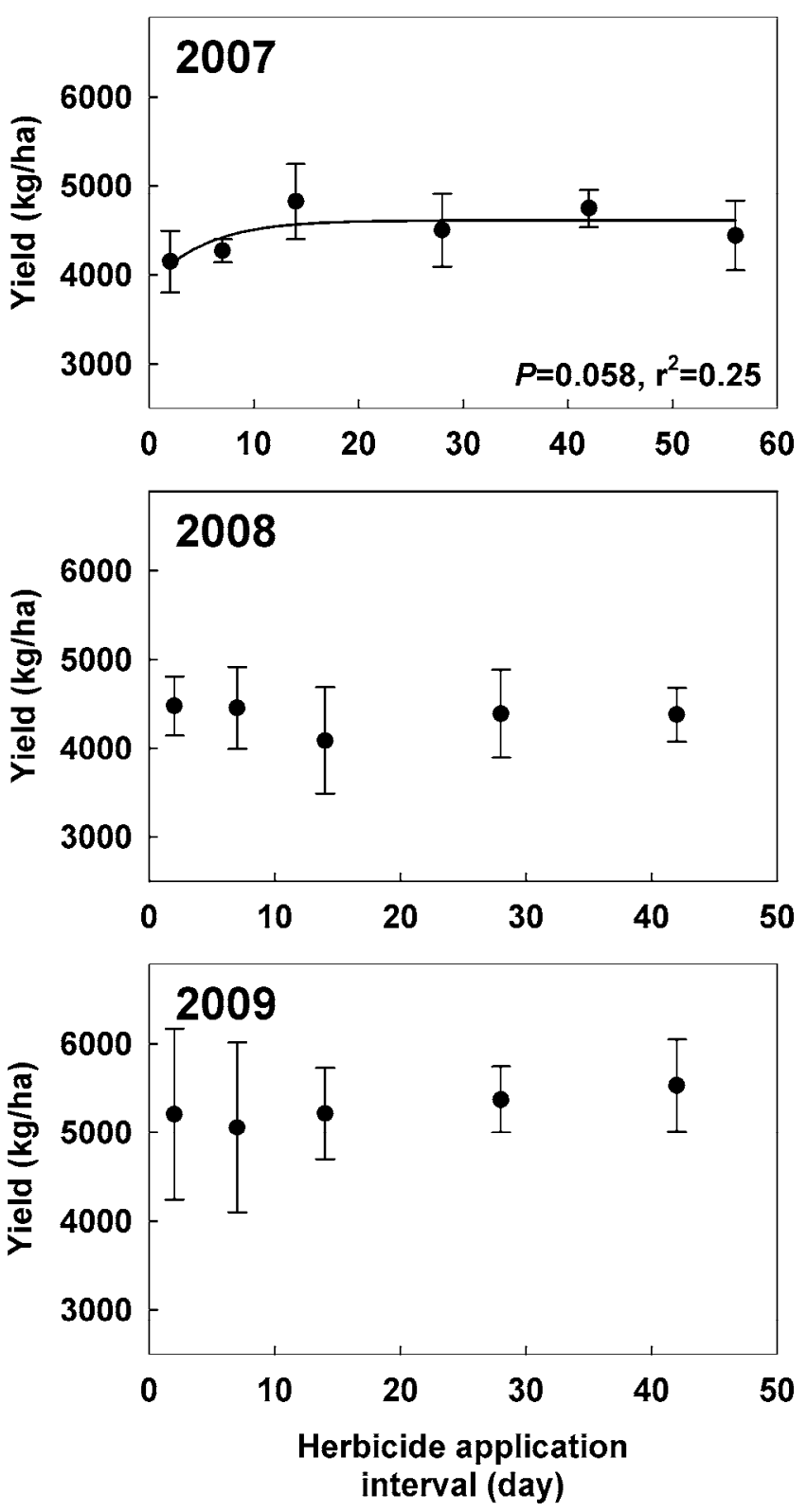

Fig. 5. Influence of herbicide application interval (time between glyphosate application and planting) on spring barley yield in Pullman, WA during 2007, 2008, and 2009. Bars indicate standard deviation of the mean. Points for 2007 are fit with a logistic regression model. $P$ value for the analysis of variance and Fisher's protected least significant difference $(P=0.05)$ were 0.04 and 497 in 2007, 0.7 and 724 in 2008 , and 0.8 and 947 in 2009 , respectively. application treatments but we did observe a decline in activity over time after planting for both $R$. solani and $R$. oryzae. Real-time PCR results indicated the highest levels of $R$. solani AG-8 inoculum at 2 and 7 days in 2009 and 2008, respectively. This increase in fungal DNA concentration was associated with an increase in disease rating. Thus we found clear evidence for a direct role of a short interval between glyphosate application and planting in increasing $R$. solani AG-8 inoculum. Increases in the incidence and severity of Rhizoctonia root rot are not due to an effect of glyphosate directly on the fungus, because in vitro studies have shown no effect of glyphosate on mycelial growth of $R$. solani (5). However, glyphosate might affect disease incidence and severity via different mechanisms. As observed in various studies, glyphosate can reduce root colonization by arbuscular mycorrhizal fungi (30), influence host susceptibility (14), stimulate the growth of selected rhizosphere fungi (13), induce sclerotia formation of $R$. solani AG4 on colonized plants, and increase sclerotia weight of $R$. solani AG-2-2 (5). An alternative explanation for how glyphosate application affects levels of disease may be due to an alteration of the population of other beneficial microorganisms that compete with or suppress Rhizoctonia spp. The dying roots, following the glyphosate application, likely change the root microflora and, thereby, severity of the disease. Therefore, inconsistencies in the effects of timing between years in this study may be explained by the effect of glyphosate on antagonistic microorganisms (1). Alternatively, it may be due to the differing effects of glyphosate on different inoculum types or replacement with different anastomosis groups of $R$. solani (25). $R$. solani survives in the soil and in crop debris in the form of hyphae and monilioid cells while $R$. oryzae survive in the form of microsclerotia (3).

Similarly, the impact of plant species on the activity and diversity of soil microorganisms has been reported in previous studies. Some host specialization by $R$. solani anastomosis groups has also been observed (29). Significant isolate-cultivar interactions have been observed with $R$. oryzae (22). Several wheat cultivars have been found to select for specific species of fluorescent Pseudomonads, which suppress the activity of $R$. solani AG-5 (15).

Soil moisture and temperature may influence the activity of Rhizoctonia spp. in the field $(4,28)$. One difference between the 3 years studied was that weed density was high in 2007 and 2008. In addition, in 2007, there was less moisture than 2009; this may have been part of the reason for the significant association with reduced yield in 2007. Downy brome (Bromus tectorum L.) and rat-tail fescue (Vulpia myuros L.) were the main weed species in our plots. Kawate et al. (10) found that treatment of downy brome with glyphosate increased populations of $F$. solani f. sp. pisi and Pythium

Table 3. Optimum herbicide application interval (days between glyphosate application and planting) required to reach 80 and $90 \%$ of maximum in shoot length, length of first true leaf, percentage of healthy seminal roots, and healthy root rating, based on a logistic model for spring barley in Pullman, WA

\begin{tabular}{lcc}
\hline & \multicolumn{2}{c}{ Application interval (days) } \\
\cline { 2 - 3 } Variable, year & $\mathbf{8 0 \%}$ & $\mathbf{9 0 \%}$ \\
\hline Shoot length & 19 & 26 \\
2007 & 25 & 33 \\
2008 & 14 & 19 \\
2009 & & \\
Length of first true leaf & 15 & 21 \\
2007 & 18 & 24 \\
2008 & 26 & 36 \\
2009 & & \\
Percent healthy seminal roots & 11 & 13 \\
2007 & 27 & 37 \\
2008 & 17 & 23 \\
2009 & & \\
Healthy root rating & 20 & 26 \\
2007 & 25 & 35 \\
2008 & 11 & 15 \\
2009 & & \\
\hline
\end{tabular}


ultimum. Therefore, variation in our results could be attributed to unequal density and distribution of natural inoculum in the field which masked treatment effects.

Grain yield was significantly reduced as a result of the different herbicide application intervals only in 2007 and not in 2008 and 2009. This is probably due to the fact that barley plants can compensate during the season for early reductions in seedling size. Similar results were seen with seed treatment trials on the same plots, where seed treatments often increased seedling health but did not statistically increase yield (20). Similarly, Smiley et al. (27) found that yield was one of the least-responsive variables to herbicide application interval.

Correlation analysis revealed a negative correlation between shoot length and disease rating. This result is consistent with Smiley et al. (27), who reported a negative correlation between shoot length and root rot index. This result is supported by Schroeder and Paulitz (26), who observed a negative correlation for shoot length and disease rating of -0.66 for $R$. solani AG- 8 and -0.70 for
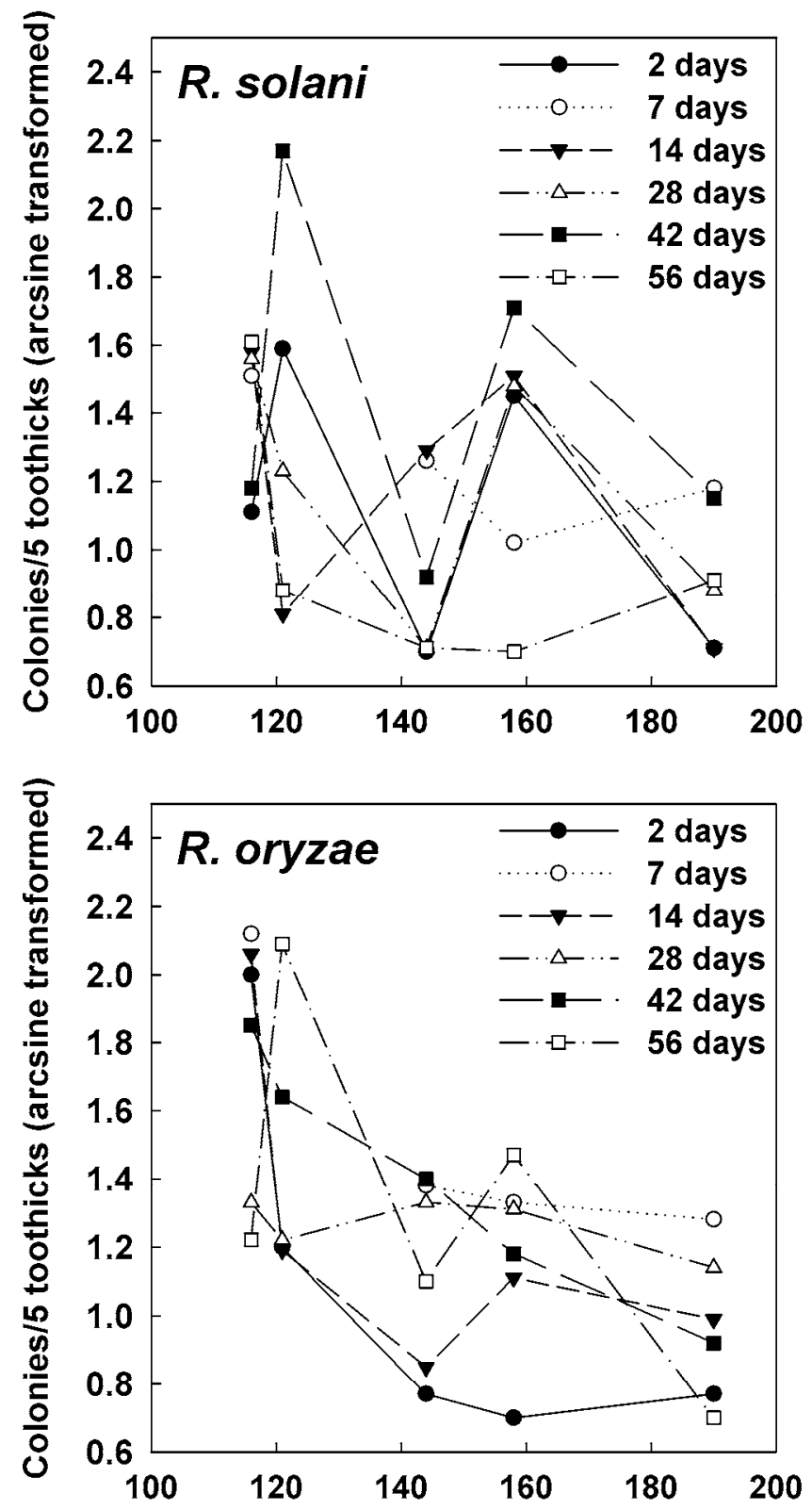

\section{Day of the year}

Fig. 6. Influence of herbicide application interval (time between glyphosate application and planting) on activity of Rhizoctonia solani and $R$. oryzae on spring barley roots in Pullman, WA during 2007.
$R$. oryzae. In this study, we also negatively correlated the number of infected seminal roots with shoot length. This result is consistent with James et al. (8), who found that shoot growth reduction was associated with root growth reduction. Similarly, Kirkegaard et al. (12) observed a reduction in shoot growth of wheat seedlings as the amount of $R$. solani AG-8 increased. Disease rating and number of infected seminal roots are destructive evaluation criteria compared with shoot length, which is easier and does not require digging and washing of roots. Therefore, shoot length could be used in a largescale experiment for disease assessment in future studies. This relationship between aboveground seedling measurements and root disease has also been observed with Pythium root rot (7).

This study highlights the importance of timely application of glyphosate to adversely affect diseases caused by Rhizoctonia spp. However, many questions remain regarding the effects of weed populations, weed species, microbial antagonists, the type of herbicide and possible carryover, and the physiological age of volunteer plants on Rhizoctonia root rot.

\section{Acknowledgments}

We thank R. Sloot and C. Watt for technical assistance. This research was supported by a grant from the Washington Grain Commission.

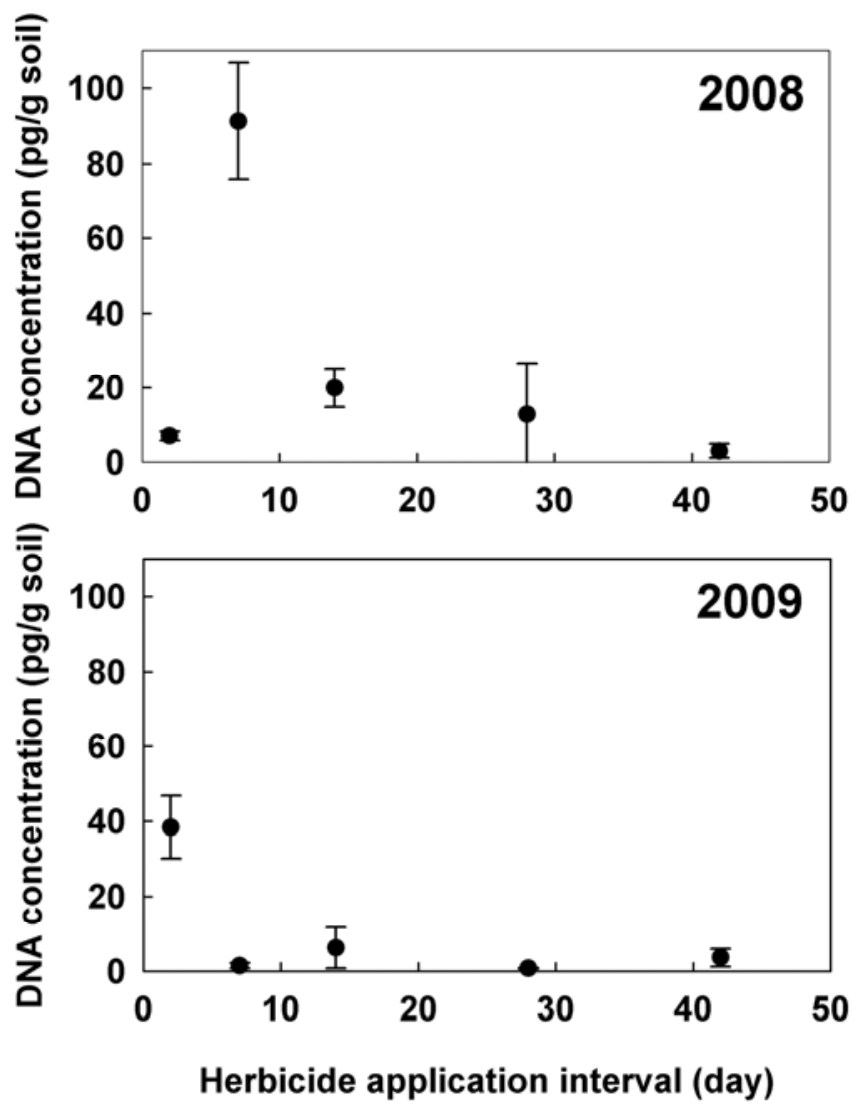

Fig. 7. Influence of herbicide application interval (time between glyphosate application and planting) on the concentration of DNA of Rhizoctonia solani AG-8 in 2008 and 2009. $P$ value for the analysis of variance and Fisher's protected least significant difference $(P=0.05)$ were 0.001 and 39.51 in 2008 and 0.01 and 27.0 in 2009 , respectively.

Table 4. Correlation between Rhizoctonia root rot rating and aboveground seedling measurements for spring barley in Pullman, WA

\begin{tabular}{lccc}
\hline & \multicolumn{2}{c}{ Pearson's coefficient of correlation $(\boldsymbol{P}$ value $)$} \\
\cline { 2 - 4 } Plant variable & $\mathbf{2 0 0 7}$ & $\mathbf{2 0 0 8}$ & $\mathbf{2 0 0 9}$ \\
\hline No. of tillers & $-0.95(0.13)$ & $-0.86(0.06)$ & $-0.17(0.97)$ \\
Shoot length & $-0.94(0.02)$ & $-0.92(0.03)$ & $-0.99(0.001)$ \\
Length of first & & & \\
true leaf & $-0.95(0.01)$ & $-0.78(0.11)$ & $-0.83(0.08)$ \\
\hline
\end{tabular}




\section{Literature Cited}

1. Barnett, S. J., Roget, D. K., and Ryder, M. H. 2006. Suppression of Rhizoctonia solani AG-8 induced disease on wheat by the interaction between Pantoea, Exiguobacterium, and Microbacteria. Aust. J. Soil Res. 44:331342.

2. Bradley, C. A., Hartman, G. L., Wax, L. M., and Pedersen, W. L. 2002. Influence of herbicides on Rhizoctonia root and hypocotyl rot of soybean. Crop Prot. 21:679-687.

3. Cook, R. J., Schillinger, W. F., and Christensen, N. W. 2002. Rhizoctonia root rot and take-all of wheat in diverse direct-seed spring cropping systems. Can. J. Plant Pathol. 24:349-358.

4. Gill J. S., Sivasithamparam K., and Smettem, K. R. J. 2001. Soil moisture affects disease severity and colonisation of wheat roots by Rhizoctonia solani AG-8. Soil Biol. Biochem. 33:1363-1370.

5. Harikrishnan, R., and Yang, X. B. 2001. Influence of herbicides on growth and sclerotia production in Rhizoctonia solani. Weed Sci. 49:241-247.

6. Herrmann, K. M., and Weaver, L. M. 1999. The shikimate pathway. Annu. Rev. Plant Physiol. Plant Mol. Biol. 50:473-503.

7. Higginbotham, R.W., Paulitz, T. C., Campbell, K. G., and Kidwell, K. K. 2004. Evaluation of adapted wheat cultivars for tolerance to Pythium root rot. Plant Dis. 88:1027-1032.

8. James, R. A., Kirkegaard, J. A., and Munns, R. 1997. Contribution of Rhizoctonia to reduced seedling growth of direct-drilled wheat: studies with intact cores. Aust. J. Agric. Res. 48:1231-1239.

9. Jarvis, R. J., and Brennan, R. F. 1986. Timing and intensity of surface cultivation and depth of cultivation effect on Rhizoctonia patch and wheat yield. Aust. J. Exp. Agric. 26:703-708.

10. Kawate, M. K., Colwell, S. G., Ogg, A. G., and Kraft, J. M. 1997. Effect of glyphosate-treated henbit (Lamium amplexicaule) and downy brome (Bromus tectorum) on Fusarium solani f. sp. pisi and Pythium ultimum. Weed Sci. 45:739-743

11. Kim, D.-S., Cook, R. J., and Weller, D. M. 1997. Bacillus sp. L324-92 for biological control of three root diseases of wheat grown with reduced tillage. Phytopathology 87:551-558.

12. Kirkegaard, J. A., Munns, R., James, R. A., and Neate, S. M. 1999. Does water and phosphorus uptake limit leaf growth of Rhizoctonia infected wheat seedlings? Plant Soil 209:157-166.

13. Kremer, R. J., Means, N. E., and Kim, S. 2005. Glyphosate affects soybean root exudation and rhizosphere micro-organisms. Int. J. Environ. Anal. Chem. 85:1165-1174.

14. Larson, R. L., Hill, A. L., Fenwick, A., Kniss, A. R., Hanson, L. E., and Miller, S. D. 2006. Influence of glyphosate on Rhizoctonia and Fusarium root rot in sugar beet. Pest Manage. Sci. 62:1182-1192.

15. Mazzola, M., and Gu, Y. 2002. Wheat genotype-specific induction of soil microbial communities suppressive to disease incited by Rhizoctonia solani anastomosis group (AG)-5 and AG-8. Phytopathology 92:1300-1307.

16. Okubara, P. A., Schroeder, K. L., Li, C., Schumacher, R. T., and Lawrence, N. P. 2008. Improved quantification of pathogen DNA from soil using pressure cycling technology. Can. J. Plant Pathol. 29:304-310.

17. Okubara, P. A., Schroeder, K. L., and Paulitz, T. C. 2008. Identification and quantification of pathogenic Rhizoctonia solani and $R$. oryzae using realtime PCR. Phytopathology 98:837-847.

18. Paulitz, T. C. 2006. Low input no-till cereal production in the Pacific Northwest of the U.S.: the challenges of root diseases. Eur. J. Plant Pathol 115:271-281

19. Paulitz, T. C., and Schroeder, K. L. 2005. A new method for the quantification of Rhizoctonia solani and Rhizoctonia oryzae from soil. Plant Dis. 89:767-772.

20. Paulitz, T. C., and Scott, R. B. 2005. Effect of seed treatments for control of Rhizoctonia root rot in spring wheat. Fungic. Nematicide Tests. 61:ST014.

21. Paulitz, T. C., Smiley, R. W., and Cook, R. J. 2002. Insights into the prevalence and management of soilborne cereal pathogens under direct seeding in the Pacific Northwest, U.S.A. Can. J. Plant Pathol. 24:416-428.

22. Paulitz T. C., Smith, J. D., and Kidwell, K. K. 2003. Virulence of Rhizoctonia oryzae on wheat and barley cultivars from the Pacific Northwest. Plant Dis. 87:51-55.

23. Roget, D. K., Venn, N. R., and Rovira, A. D. 1987. Reduction of Rhizoctonia root rot of direct-drilled wheat by short-term chemical fallow. Aust. J. Exp. Agric. 27:425-430.

24. Sanogo, S., Yang, X. B., and Scherm, H. 2000. Effects of herbicides on Fusarium solani $\mathrm{f}$. sp. glycines and development of sudden death syndrome in glyphosate-tolerant soybean. Phytopathology 90:57-66.

25. Schneider, J. H., Kocks, M. K., and Schilder, M. T. 2001. Possible mechanisms influencing the dynamics of Rhizoctonia disease of tulips. Eur. J. Plant Pathol. 107:723-738.

26. Schroeder, K. L., and Paulitz, T. C. 2008. Effect of inoculum density and soil tillage on the development and severity of Rhizoctonia root rot. Phytopathology 98:304-314.

27. Smiley, R. W., Ogg, A. G., Jr., and Cook, R. J. 1992. Influence of glyphosate on Rhizoctonia root rot, growth, and yield of barley. Plant Dis. 76:937-942.

28. Smiley, R. W., and Uddin, W. 1993. Influence of soil temperature on Rhizoctonia root rot ( $R$. solani AG-8 and $R$. oryzae) of winter wheat. Phytopathology 83:777-785.

29. Sturz, A. V., Johnston, H. W., and MacWilliams, C. K. 1995. Weed hosts of Rhizoctonia solani in Prince Edward Island. Can. J. Plant Pathol. 17:346352.

30. Wan, M. T., Rahe, J. E., and Watts, R. G. 1998. A new technique for determining the sublethal toxicity of pesticides to the vesicular-arbuscular fungus Glomus intraradices. Environ. Toxicol. Chem. 17:1421-1428. 